Pinkerton, Evelyn and Martin Weinstein

1995. Fisheries That Work: Sustainability Through Community-Based Management. A Report to the David Suzuki Foundation. The David Suzuki Foundation, Vancouver, Canada.

Warren, D. Michael, L. Jan Slikkerveer, and David Brokensha, editors

1995. The Cultural Dimension of Development. Intermediate Technology Publications, London.

Warren, D. Michael.

1993. Background to the International Symposium on Indigenous Knowledge and Sustainable Development Indigenous Knowledge and Development Monitor, 1(2) (June) URL: http://www.nuffic.nl/ciran/ikdm/1-2/articles/background.html

World Bank, et al.

1997. Towards An Integrated Coastal Zone Management Strategy for Ghana. The Environmental Protection Agency, Accra, Ghana and the World Bank, Washington D.C.

\title{
Third World in the First: Development and Indigenous Peoples, by Elspeth Young, 1995. London and New York: Routledge. 304 pp.
}

\section{Reviewed by James Waldram, Department of Native Studies, University of Saskatchewan}

This book compares Aboriginal peoples' experiences with processes of development in Canada and Australia. The emphasis is on remote areas of these two countries, and the comparison is striking. Particular attention is paid to government policies and selected industries, such as mining and tourism. Young also looks at the traditional, landBbased economies of Aboriginal peoples in the two countries, and concludes her study with an examination of Aboriginal development initiatives. In the latter case, particular emphasis is placed on sustainable development as a strategy.

This is a lushly produced book, complete with many photographs, figures and tables. It demonstrates the value of international comparisons of Indigenous issues, and transcends academic disciplines. A geographer by training, Young focuses on the land and the relationship of Aboriginal peoples to it. Her extensive research, however, includes accessing historical and anthropological studies in addition to those of geography. The use of excerpts from her own field notes, recorded while undertaking research with Aboriginal peoples in the two countries, adds a humanistic, anthropological feel to her work.

The volume demonstrates some theoretical problems. Of particular note is Young's failure to adequately explain her adoption of the Third World paradigm as a framework for understanding Indigenous minorities within liberal, democratic states. She notes only in passing the existence of a Fourth World paradigm, which other authors have suggested more adequately describes the situation of these Indigenous peoples. We are left wondering why she rejects the Fourth World paradigm. The use of the Third World as a framework obfuscates the very real political and economic differences between 
Indigenous peoples in Canada/Australia with those in, say, African nations where they are the majority and even in control of the state. Although it is emotionally appealing to refer to Aboriginal peoples as living in Third World conditions, the comparison is debatable. Young fails to comprehend the impact of state-supported programs such as medicare, education allowances, and housing. Few Aboriginal people in Canada, at least, die of protein/calorie malnutrition, in contrast to many areas of Africa. These are not petty differences, and they require considerably more thought than has been applied here. So, whereas the comparison works on one level, theoretically the volume is lacking. This should not deter those interested in international development issues, however, for the author has done a credible job researching and collating a large amount of information on the two countries. Comparisons such as we have here serve to advance our understanding of the effects of globalization on the world's Indigenous peoples.

\title{
Folk Management in the World's Fisheries: Lessons for Modern Fisheries Management, Christopher L. Dyer and James R. McGoodwin, editors. 1994. Niwot, CO: University Press of Colorado. xiv, 339
}

\section{pp.}

\author{
Reviewed by Patricia M. Clay, National Marine Fisheries Service, \\ Woods Hole, MA
}

This is a well-written book that addresses two questions currently debated hotly in fishery management circles: How do we address the worldwide decline in fishery resources? and To what extent can and should fisherfolk have a significant voice in the management process?

Offered as one possible response to both is the concept of "folk management." Folk management, as defined by this volume's editors, is related to such terms as "indigenous management," "community-based management," and "bottom-up management." Whereas these other terms are often primarily based on the management of space (that is, systems of tenure), Dyer and McGoodwin regard folk management as more broadly encompassing, also including effort limitation and stock productivity enhancement. Folk management is part of a people's fishing "technology," broadly construed, and includes an ideational component.

This volume seeks to document cases of folk management worldwide, to analyze the components of their success or failure, and to offer these insights to modern fishery managers in hopes of contributing to a more collaborative form of fisheries management-what has been described in much recent literature and some of the case studies in this volume as "co-management." Case studies are presented primarily from the Americas, but touching on several continents and including diverse fishing regimes. Pomeroy writes about institutional arrangements across multiple jurisdictions in the highland Lake Chapala district of Mexico, whereas McGoodwin presents another Mexican case from the rural Pacific coast. Cases presented by Palmer and Felt are from the North Atlantic, 